\title{
Knowledge Management for Learning: ICT System Affordances and the Impact of Order of Use
}

\author{
Regina Collins \\ New Jersey Institute of \\ Technology (NJIT) \\ rsb24@njit.edu
}

\author{
Starr Roxanne Hiltz \\ Center for Integrated Emergency \\ Management, University of Agder, \\ Norway; and NJIT \\ roxanne.hiltz@gmail.com
}

\author{
Fadi P. Deek \\ New Jersey Institute of \\ Technology \\ fadi.deek@njit.edu
}

\begin{abstract}
Knowledge management (KM) is an important activity in corporations and organizations and is well suited as a learning activity in higher education. However, integrating such activities for learning requires alignment between required activities and information technology (IT) system affordances. Using KM-based assignments requiring individual and collaborative (group) Internet-based research, this study explores the affordances of two different ITs: one the university's learning management system, and the other a Web 2.0 social digital curation system (Pearltrees). Results suggest that, despite already being familiar with Moodle, students found Pearltrees not complex and generally compatible with their learning activities, although their perceptions were impacted by whether they used Pearltrees for the first or second assignment. Students' comments indicated that mature discussion capabilities and a visual interface with the ability to organize digital resources were some of the most important affordances for tools used in KM learning activities.
\end{abstract}

\section{Introduction}

Knowledge is one of the key drivers of business success and innovation, and it is a critical part of today's knowledge economy [8]. Corporations invest heavily in knowledge management tools, encouraging and training employees to develop and share knowledge and expertise in order to increase productivity and maintain competitiveness [32, 33]. Higher education is also "in the knowledge business" [24], and KM activities have been previously explored in the educational domain, with prior studies focusing on the use of KM in higher education institutions [12, 25], students' motivations and personal characteristics (e.g. trust, reciprocity) that drive knowledge sharing in educational settings [34], or the development of proprietary systems to facilitate $\mathrm{KM}$ activities for learning [36, 38]. This research instead explores two existing information and communication technologies (ICTs) and the affordances they provide to support KM activities for learning.

Because the information technology (IT) artifact plays an important role in students' participation in KM activities for learning [36], this study evaluates the affordances of two readily available ICT systems against KM-related learning activities. Moodle is an open source learning management system widely used at universities. In this study, Moodle is considered the baseline ICT because it is the unversity's Learning Management System (LMS) and was already familiar to students. Pearltrees, a social digital content curation system that is generally unfamiliar to students but has capabilities closely aligned with the activities necessary for a KM assignment, was selected as an alternative after evaluating a number of Web 2.0 technologies that provided similar affordances such as the ability to save and store digital resources, the ability to work in teams, and commenting and discussion capabilities. Because Pearltrees was unfamiliar to students, its complexity of use and compatibility with the required KM learning activities was assessed to identify any preferences based on students' established habits and pre-existing familiarity with Moodle [16].

The KM-focused assignment began with students conducting individual research using digital media found on the Internet. Students subsequently shared their stored digital resources with their group members to complete a related group research assignment. A similar assignment was repeated a second time later in the semester to allow a comparison of system affordances. Because students completed two similar KM assignments and alternated the system used, this study enables a comparison of students' perceptions 
about using Moodle and Pearltrees for such assignments, an investigation of how the order or timing of system use affects students' perceptions, and an exploration of the effect habit plays on the introduction of a new system. More explicitly, this research is guided by the following research questions:

RQ1: How do students perceive the complexity and compatibility of an unfamiliar system such as Pearltrees when it is introduced for KM-based assignments?

RQ2: Did the order in which students used Pearltrees affect their perceptions of its complexity and compatibility?

RQ3: After using both systems for similar assignments, what were the affordances that students felt were best and least suited to a KM learning activity, and which system did students prefer overall for this type of learning activity?

In the remainder of this paper, related literature and derived hypotheses are discussed. These are followed by a description of methodologies and results. Discussion of the significance of the results, as well as limitations of the research, conclude the paper.

\section{Related Literature}

To determine the applicability of ICTs to KM learning assignments, it is important to identify typical KM activities that would need to be scaffolded by ICT system affordances. It is important to note, however, that technologies may support the same activities in different ways. Therefore, the following sections highlight KM-related learning activities and then provide more detailed discussions of how these activities are supported in the two ICTs used in this study: Moodle and Pearltrees.

\subsection{Knowledge Management Activities}

Prior studies have suggested that KM activities are closely aligned with collaborative learning [35, 36]. Davenport and Prusak [8] have identified four distinct knowledge conversion activities common in $\mathrm{KM}$ : Comparison (examining information against what is already known), Consequences (determining whether the information is sufficient to satisfy the knowledge need), Connections (identifying the relationship between this and other knowledge), and Conversation (exploring what others think). Similar activities have been identified in studies focusing on collaborative learning systems for KM [36]. These researchers identified the following key activities: knowledge gathering, knowledge analysis, knowledge construction, and knowledge sharing. Knowledge analysis can further be disaggregated into the following activities: selecting the appropriate information, organizing it, determining its appropriateness, and integrating the knowledge with other available knowledge [37, 38].

In a learning assignment, these activities can be encouraged through tasks such as conducting research using digital resources, identifying multiple resources to satisfy the knowledge need, organizing the resources according to some logical classification, sharing the resources and integrating them through discussion or commenting. The six assignments used in this research were developed specifically to require the above KM activities in order to assess the suitability of the two systems.

\subsection{Information and Communication Technologies as Knowledge Management Systems}

Having identified the activities required for the KM-focused learning assignments, the next step was to identify ICTs that adequately supported these activities. While neither of the selected ICTs was specifically designed for the purposes of KM, each supports the KM activities listed, making them suitable for evaluation.

Moodle is the university's open source learning management system (LMS). Pearltrees, is a Web 2.0 [20] social digital curation system. Pearltrees was selected after evaluating a number of similar Web 2.0 technologies (including Pinterest, Scoop.It, and Storify) because it was most closely aligned with the required $\mathrm{KM}$ activities.

Each of these systems is discussed individually below. This is followed by a comparison of the affordances of both systems.

2.2.1. Moodle. The first version of a learning management system (LMS) was the Virtual Classroom developed during the 1980s and later refined for the new Web technology in the 1990s [10]. These systems were built on a traditional classroom metaphor while at the same time taking advantage of computer-mediated communication capabilities. Since then, a number of commercial and open source LMS systems, all supporting similar activities, have been developed. One such widely available, open source LMS is Moodle.

Moodle is designed as a platform for distance and online learning and provides capabilities such as discussion forums and wikis in which students can post links to digital resources while also providing annotations and comments. Moodle's discussion 
forums are threaded, hierarchical discussions showing the evolution of the conversation both chronologically (newest to oldest) and relationally (who replied to whose posting). Moodle forums also provide advanced capabilities such as peer ratings of postings: however, Moodle has very limited capabilities for learners to organize their resources into meaningful hierarchies.

2.2.2. Pearltrees. Pearltrees is a social digital media curation system that enables management of an individual's digital resources (pearls) through a visual, hierarchical tree structure and supports sharing of resources through the creation of teams. Pearltrees is one of many Web 2.0 technologies that encourage social knowledge sharing. Other examples include wikis and blogs [3, 6, 7, 9, 11, 27] and social tagging sites [21, 29, 31]. Prior studies have found that many of these technologies support the types of activities required to integrate $\mathrm{KM}$ into collaborative learning [18, 36, 38].

Pearltrees provides a browser add-on that enables learners to search the Internet for helpful learning resources and, with one click, add and organize those resources into their hierarchy. Pearltrees' graphical, drag-and-drop interface enables learners to easily capture, organize, and share knowledge resources. Notes and comments provide learners with the ability to discuss their resources.

Because of its inherent affordances for the development of social capital and knowledge sharing, Pearltrees has been tested as a tool to facilitate peer-topeer learning in a Massive Open Online Course (MOOC) [22] and as a tool for collating digital resources for radiology education [15]. In this study, it is tested for its suitabililty as a KM tool for learning.

2.2.3. Comparison of Affordances. After evaluating their respective affordances, Moodle and Pearltrees were determined to provide sufficiently similar affordances for the KM activities required for learning. Table 1 provides a comparison of the affordances of the two ICT systems.

Table 1. Comparison of Activities and System Affordances

\begin{tabular}{|l|l|l|}
\hline Activity & Moodle & Pearltrees \\
\hline Knowledge gathering & $\begin{array}{l}\text { Students copy and paste links to digital } \\
\text { resources in a discussion forum. } \\
\text { Students could choose whether to store } \\
\text { all links in one posting or create } \\
\text { separate postings for each link. }\end{array}$ & $\begin{array}{l}\text { Students use the browser plug-in to store } \\
\text { live links to resources into their account. } \\
\text { The plug-in prompts students to specify } \\
\text { where the resource should be placed in } \\
\text { their organizational hierarchy, or students } \\
\text { can use the drag-and-drop interface to } \\
\text { move resources. }\end{array}$ \\
\hline $\begin{array}{l}\text { Knowledge analysis } \\
\text { and sharing }\end{array}$ & $\begin{array}{l}\text { Students can add comments and } \\
\text { annotations about their resources in } \\
\text { theirdiscussion forums. }\end{array}$ & $\begin{array}{l}\text { Students can attach notes or annotations to } \\
\text { each individual resource in their hierarchy. }\end{array}$ \\
\hline $\begin{array}{l}\text { Students can share their resources by } \\
\text { copying the links into their group } \\
\text { discussion forum and use posts to } \\
\text { discuss the resources. }\end{array}$ & $\begin{array}{l}\text { Students can click on resources they wish } \\
\text { to share with their group members in their } \\
\text { team area. They can use comments } \\
\text { attached to each resource for discussion. }\end{array}$ \\
\hline
\end{tabular}

\subsection{Introduction of a New System}

Prior research has suggested that an important component of adoption and continued usage of a new ICT is habit [16]. Habit was found to act as a moderating variable in the relationship between intentions to use an ICT and actual continuance behavior. Because Moodle was familiar to students and was already being used in each of the courses prior to initiating the study assignments, this research focuses on evaluating students' perceptions of Pearltrees as an unfamiliar but well-suited alternative ICT for KM learning activities. Students' perceptions of the complexity and compatibility of having to use an unfamiliar system (Pearltrees) provide insights into the difficulties of introducing alternative systems for such activities.

2.3.1. Complexity of using Pearltrees. Because students were already familiar with Moodle as the university'sLMS, and had used it from the beginning of the course, this study explores the extent to which students perceived that having to use Pearltrees in addition to Moodle complicated their learning tasks (complexity). Complexity measures the extent to which a system is perceived as difficult to use or understand [23, 26]. Early research exploring the 
impact of complexity on adoption of new technologies found that, as the complexity of a technological innovation increased, the rate of its adoption decreased $[26,28]$. Complexity is perceived as one of the key characteristics of innovation diffusion theory (IDT) [1] and has been found to negatively affect usage and expected usage of ICT systems [14].

Because Pearltrees is unfamiliar to most students, it could be perceived as complex. However, the complexity of having to learn Pearltrees was expected to be minimized due to its browser integration, KM affordances, and graphical, drag-and-drop interface. This suggests the following hypothesis:

Hla: Due to its interface and system affordances, students will perceive Pearltrees as having low complexity.

2.3.2. Compatibility of using Pearltrees. Similarly, because students were already familiar with Moodle, this study prompted students about the extent to which using Pearltrees was compatible with their learning style. Compatibility measures the degree to which an innovation is perceived as being consistent with existing values, needs, and experiences of potential adopters [19]. Studies have shown that the compatibility of a KM system has a positive relationship with the system's perceived usefulness, perceived ease of use, and task technology fit [13]. This suggests the following hypothesis:

H1b: Due to its KM affordances, students will perceive Pearltrees as having high compatibility with the learning activity.

2.3.3. Order of system use. The repeated measures design of this research was chosen to enable an exploration of the effect of the order or timing with which a new system is introduced into coursework. Because Moodle was already familiar to the students and was already being used in the courses, this impact was evaluated only through students' perceptions when using Pearltrees. Because prior research has explored the general decline in student participation and increase in drop-out rate as a course progresses [4], habit is expected to have a more significant effect for students who used Pearltrees later in the course (for the second assignment). This suggests the following hypotheses:

H2a: Students who use Pearltrees for the second assignment will perceive it as more complex than students who use it for the first assignment.

H2b: Students who use Pearltrees for the second assignment will perceive it as less compatible than students who use it for the first assignment.

Finally, because students were exposed to both Moodle and Peartlrees, research question 3 captures students' perceptions of the strengths and weaknesses of both systems, as well as which system they preferred overall and why.

\section{Research Methodology}

This research is a mixed-methods study [30] that includes quantitative and qualitative analyses of student survey responses when two assignments of similar design were incorporated into 16-week long, graduate-level courses in Information Systems at a large technological university in the northeastern United States. Because this research involves formal learning activities, the study was first approved by the university's Institutional Review Board. Afterwards, the researcher worked with instructors to modify or create assignments that would require KM activities for learning.

Prior to this larger study, a pilot test was conducted to evaluate the suitability of the two systems, as well as assignment instructions and survey instruments. Results from the pilot study suggested slight modifications to the survey instruments and assignment instructions, and also indicated that students found the use of Moodle wikis confusing for storing, managing, and sharing digital resources. Therefore, in this study, students used discussion forums during the Moodle condition for resource storage, sharing, and discussion.

Students were randomly assigned to groups at the beginning of the semester: students in odd-numbered groups used Moodle for the first assignment, while students in even-numbered groups used Pearltrees first. For each assignment, students were instructed to 1) conduct individual research using digital media found on the Internet, 2) store the links to the digital content to inform an individual assignment, and 3) subsequently share and discuss their digital media with group members for a group assignment. Individual assignments were completed either in private Moodle discussion forums or individual Pearltrees accounts. For the group activity, students using Moodle were provided with private group forums; in Pearltrees, the researcher created teams and then invited students to join. Four to six weeks later, these same groups were instructed to use the system they did not already use for a second, similar assignment. Because the assignments were part of their coursework, students were required to complete both assignments (each consisting of individual and group parts) but were invited to participate in the research part of the assignments (the surveys) for extra credit.

Surveys consisted of a pre-assignment survey (O1) and a post-assignment survey (O2) for the first assignment, and a slightly modified pre-assignment (O3) and post-assignment (O4) surveys before and 
after the second assignment, resulting in a $2 \times 2$ repeated measures cross-over design. This cross-over design facilitated a comparison of the two ICTs.

The post-assignment survey during the Pearltrees condition included statements capturing students' perceptions about the extent to which having to use Pearltrees complicated the learning task (complexity) and the extent to which Pearltrees was compatible with their learning activities (compatibility). Regardless of order of system usage, the second post-assignment survey also included five open-ended questions asking what students liked best and least about each system and which system they preferred overall.

In total, six assignments in three courses (two semesters of an Information Systems Principles course and one semester of an Information Systems Strategy course) were included in this study. The measurement scales for complexity [26] and compatibility [19] were adapted from prior research; sample items are shown in Tables 4 and 5. All of the responses were based on a five-point, Likert-type scale ranging from Strongly Disagree (1) to Strongly Agree (5) with a Neutral option (3).

Responses from the pre- and post-assignment surveys were first screened individually for unengaged responses and were subsequently merged by matching student identifiers. The final sample contained 90 complete survey responses. All quantitative data analysis was conducted using IBM SPSS Version 22.0.0.1. General perceptions of complexity and compatibility were evaluated using a one-sample t-test. Differences between perceptions from the two assignments were evaluated using an independent samples t-test. Because this is the first study of this type, results that are significant at the $90 \%$ confidence level are described as "suggesting" differences, while those significant at the $95 \%$ confidence level are described as "significant."

Thematic analysis [2] was used to explore students' responses to the open-ended survey questions about the two systems, as coded by the first author using a combination of broad categories defined by each question and "grounded theory" [17] to surface major themes. Students' comments evidencing the major themes are provided as illustration in Section 4.4.

\section{Results}

The results of this research begin with a description of participant demographics. This is followed by discussions of the results addressing each of the three research questions and testing the hypotheses.

\subsection{Participant Demographics}

Demographic information including gender and degree program were captured at the beginning of the first pre-assignment survey. Results are summarized in Table 2, which also shows the number of students in each treatment condition.

Table 2. Participant demographics

\begin{tabular}{|l|c|c|}
\hline \multicolumn{3}{|c|}{ Demographic Data (N=90) } \\
\hline Gender & $\begin{array}{c}61 \text { Male } \\
(67.8 \%)\end{array}$ & $\begin{array}{c}29 \text { Female } \\
(32.2 \%)\end{array}$ \\
\hline $\begin{array}{l}\text { Assigned System } \\
\text { for } 1^{\text {st }} \text { assignment }\end{array}$ & $\begin{array}{c}47 \text { Moodle } \\
(52.2 \%)\end{array}$ & $\begin{array}{c}43 \text { Pearltrees } \\
(47.8 \%)\end{array}$ \\
\hline \multicolumn{2}{|c|}{ Degree Program } \\
\hline Information Systems & $43(47.8 \%)$ \\
\hline MBA & $11(12.2 \%)$ \\
\hline $\begin{array}{l}\text { Other (e.g. Information Technology, } \\
\text { Business Information Systems) }\end{array}$ & $36(40.0 \%)$ \\
\hline
\end{tabular}

\subsection{Complexity and Compatibility of Using Pearltrees}

Research question 1 explores students' general perceptions of the complexity (H1a) and compatibility (H1b) of Pearltrees with this type of learning assignment, regardless of the assignment during which Pearltrees was used. A one-sample t-test was used to evaluate differences from the mean for these two variables. The Complexity scale contained five items with a potential range from 5 to 25 and a neutral value of 15 , while the Compatibility scale included 3 items with a potential range from 3 to 15 with a neutral value of 9. Results of the one-sample t-test show that students' perceptions of Pearltrees were generally positive, with the complexity variable significantly lower and the compatibility variable significantly higher than their neutrals. Results are shown in Table 3 .

Table 3. One-sample t-test for complexity and compatibility

\begin{tabular}{|l|c|l|c|}
\hline Variable & Neutr. & $\begin{array}{l}\text { Mean } \\
\text { SD }\end{array}$ & t, Sig. \\
\hline Complexity & 15 & $\mu=12.89$ & $\mathrm{t}(89)=-4.25$, \\
& & $\mathrm{SD}=4.71$ & $p<.001$ \\
\hline Compatibility & 9 & $\begin{array}{c}\mu=10.49 \\
\mathrm{SD}=2.59\end{array}$ & $\begin{array}{c}\mathrm{t}(89)=5.47, \\
\end{array}$ \\
\end{tabular}

These results indicate that students felt that Pearltrees was not complex to use for this type of assignment; H1a was therefore supported. Similarly, results suggest that Pearltrees was compatible with the learning activities involved in the assignment; $\mathrm{H} 1 \mathrm{~b}$ is supported. Together, these results suggest that a 
system that has simple-to-use KM affordances, even if unfamiliar to students, can result in positive perceptions about using the system for learning asignments requiring $\mathrm{KM}$ activities.

\subsection{Effect of Order of Usage on Perceptions of Pearltrees}

To evaluate whether the timing of the introduction of a new system into KM-based learning activities has an impact on students' perceptions, research question 2 explores the complexity and compatibility variables based on whether Pearltrees was used for the first or second assignment.

4.3.1. Complexity of Pearltrees when used second. An independent samples t-test of the complexity construct suggests that the order in which students were exposed to Pearltrees did have an effect on their perceptions of its complexity, with students using it second reporting that they perceived Pearltrees as more complex. An exploration of the individual scale items reveals that, between assignments one and two, one item differed at the $95 \%$ confidence level and two of the five items differed at the $90 \%$ confidence level. Differences are shown in Table 4.

Table 4. Independent samples t-test of complexity

\begin{tabular}{|c|c|c|c|}
\hline \multicolumn{2}{|l|}{ Complexity } & Mean & SD \\
\hline \multicolumn{2}{|l|}{ Pearltrees for A1 (43) } & 11.81 & 3.94 \\
\hline \multicolumn{2}{|l|}{ Pearltrees for A2 (47) } & 13.87 & 5.17 \\
\hline \multicolumn{4}{|l|}{$\mathrm{t}=2.11, p=0.04$} \\
\hline Statement & Asgnt & Mean & SD \\
\hline \multirow{3}{*}{$\begin{array}{l}\text { Working with Pearltrees } \\
\text { is so complicated, it is } \\
\text { difficult to understand } \\
\text { what is going on. }\end{array}$} & $\begin{array}{l}\text { A1 \& } \\
\text { A2 }\end{array}$ & 2.49 & 1.03 \\
\hline & A1 & 2.23 & 0.87 \\
\hline & $\mathrm{A} 2$ & 2.72 & 1.12 \\
\hline \multicolumn{4}{|l|}{$\mathrm{t}=2.31, p=0.02$} \\
\hline \multirow{3}{*}{$\begin{array}{l}\text { Using Pearltrees } \\
\text { involves too much time } \\
\text { storing and managing } \\
\text { my Internet resources. }\end{array}$} & $\begin{array}{l}\text { A1 \& } \\
\text { A2 }\end{array}$ & 2.54 & 1.10 \\
\hline & A1 & 2.33 & 0.92 \\
\hline & $\mathrm{A} 2$ & 2.75 & 1.22 \\
\hline \multicolumn{4}{|l|}{$\mathrm{t}=1.82, p=0.07$} \\
\hline \multirow{3}{*}{$\begin{array}{l}\text { It takes too long to learn } \\
\text { how to use Pearltrees to } \\
\text { make it worth the effort. }\end{array}$} & $\begin{array}{ll}\text { A1 \& } \\
\text { A2 }\end{array}$ & 2.44 & 1.25 \\
\hline & A1 & 2.21 & 1.06 \\
\hline & $\mathrm{A} 2$ & 2.66 & 1.37 \\
\hline
\end{tabular}

These results suggest that students who were exposed to Pearltrees during the second assignment found that it was more complex to integrate Pearltrees into their learning activity than students who used
Pearltrees for the first assignment. $\mathrm{H} 2 \mathrm{a}$ is therefore supported. This finding suggests that integrating new systems is perceived as somewhat more complex later in the semester.

4.3.2. Compatibility of Pearltrees when used second. Analysis of the compatibility construct revealed that the timing of students' exposure to Pearltrees again had an influence on their perceptions. At the variable-level, this difference was significant only at the $90 \%$ confidence level. To further explore this difference, each item in the compatibility scale was analyzed individually; two of the three items resulted in significant differences at the $95 \%$ confidence level. Significant differences are shown in Table 5.

Table 5. Independent samples t-test of compatibility

\begin{tabular}{|c|c|c|c|}
\hline \multicolumn{2}{|c|}{ Compatibility } & Mean & SD \\
\hline \multicolumn{2}{|l|}{ Pearltrees for A1 (43) } & 11.00 & 2.31 \\
\hline \multicolumn{2}{|l|}{ Pearltrees for A2 (47) } & 10.02 & 2.75 \\
\hline \multicolumn{4}{|l|}{$\mathrm{t}=-1.82, p=0.07$} \\
\hline \multirow{4}{*}{$\begin{array}{l}\text { Statement } \\
\text { Using Pearltrees is } \\
\text { compatible with all } \\
\text { aspects of my } \\
\text { learning. }\end{array}$} & Assgnmt & Mean & SD \\
\hline & $\mathrm{A} 1 \& \mathrm{~A} 2$ & 3.51 & 0.99 \\
\hline & $\mathrm{A} 1$ & 3.70 & 0.99 \\
\hline & $\mathrm{A} 2$ & 3.26 & 0.83 \\
\hline \multicolumn{4}{|l|}{$\mathrm{t}=-2.29, p=0.03$} \\
\hline \multirow{3}{*}{$\begin{array}{l}\text { I think that using } \\
\text { Pearltrees fits well } \\
\text { with the way I like to } \\
\text { manage my learning } \\
\text { resources. }\end{array}$} & $\mathrm{A} 1 \& \mathrm{~A} 2$ & 3.51 & 0.98 \\
\hline & $\mathrm{A} 1$ & 3.72 & 0.85 \\
\hline & A2 & 3.32 & 1.05 \\
\hline \multicolumn{4}{|l|}{$\mathrm{t}=-1.99, p=0.05$} \\
\hline
\end{tabular}

These results suggest that $\mathrm{H} 2 \mathrm{~b}$ is supported, but only at the $90 \%$ confidence level, with students reporting lower perceptions of the compatibility of Pearltrees with their KM learning activities when they used Pearltrees for the second assignment of this type.

To ensure that these differences were not related to more time elapsing between the second assignment and the first, a Pearltrees video tutorial was provided to students at the beginning of the research assignment. Approximately $65 \%$ of students watched the tutorial (65.1\% of students who used Pearltrees for the first assignment and $63.3 \%$ of students who used Pearltrees for the second assignment) suggesting that timing of the system overview was not the issue.

Together, the results for compatibility and complexity suggest that perceptions about an unfamiliar system used for an assignment are affected by the time at which the usage occurs, with preference given to introducing new systems earlier in the semester. 


\subsection{Analysis of Student Comments}

To explore students' perceptions about the affordances of both Moodle and Pearltrees for this type of assignment (RQ3), the final post-assignment survey included five open-ended questions about these two ICT systems. Two questions about each system prompted students to explain what they liked best and least about using that system for this type of assignment. The final open-ended question asked students to explain which system they felt provided better affordances for completing this type of assignment. The results of the thematic analysis are described briefly below, with one or two illustrative quotes provided for each theme.

4.4.1. What students liked best about Moodle. First, because assignments had to be submitted through Moodle (regardless of whether the students used Pearltrees or Moodle to manage and share resources), several students felt that this simplified their activities, e.g., "It makes it easier to go to one place."

Other students focused on the fact that they were already experienced and comfortable using Moodle. Said one student, "Since we were used to Moodle from [the] beginning we didn't want to learn anything new." A few students noted specific affordances provided by Moodle which are not available or are not as well integrated in Pearltrees. One student liked the fact that Moodle provides "... e-mail notifications when other members post." Although Pearltrees provides Comment and Note capabilities, they are not as intuitive and user-friendly as Moodle's discussion forums, leading another student to state that Moodle was "easy for discussion."

4.4.2. What students liked least about Moodle. A number of students mentioned Moodle's inability to easily share Internet resources. Said one student, "[Moodle] does not provide instant access to information as soon as the team members posted them, plus the websites were just links unlike Pearltrees." Another student said, "Storing the references [in Moodle] was just seeing the links as an output, but no graphics or interactive data could be seen..."

4.4.3. What students liked best about Pearltrees. Students focused on the visual interface of Pearltrees, the ease of storing resources, and the ease of sharing those resources with their teammates. In general, students commented that Pearltrees has a "very good design and has a lot of features."

Responses about sharing Internet resources on Pearltrees focused on the ease of sharing. Said one student, "Pearltrees is graphically very appealing and [I] just have to add [the URL] to share web content [with] group members [who] can see thumbnail of the shared content."

4.4.4. What students liked least about Pearltrees. Students felt the demands of having to use another system were taxing, e.g., Pearltrees created "one more extra account to maintain." Students also complained that "it is hard to communicate within the team using the system."

4.4.5. Which system is better for assignments using digital media resources? Of the 49 students who provided responses to the final question about which system they felt had better tools for completing this type of assignment, opinions were split, with 25 students stating that they preferred Pearltrees and 24 stating that they preferred Moodle or an improved version of Moodle. Students who preferred Moodle generally mentioned Moodle's familiarity (habit) as a principle benefit: "It is more convenient for students as they are more used to the Moodle system and how it works."

Several students stated that they preferred Moodle because it had better affordances for communication between students. One student said that she definitely preferred Moodle for this type of assignment because it required " ... a strong communication with group members." Similarly, another student stated, "Moodle is better, since it [provides] a mature way for us to interact with each other."

Students who preferred Pearltrees for this type of assignment focused on Pearltrees' graphical interface and richer sharing capabilities. One student stated that Pearltrees made it "easier to manage and store resources." Another commented that Pearltrees "has [a] drag and drop option. It can be used to invite people..." to share.

Several students felt that Pearltrees was generally more suited to assignments requiring $\mathrm{KM}$ activities. "I think that Pearltrees definitely wins over Moodle. The reason being that as I got used to Pearltrees, the more easier (sic) it was to store and share data with teammates." Similarly, one student said that Pearltrees was "better since this assignment required us to use Internet resources extensively. Pearltrees help[ed] gather the website information and organized them for easy access."

\section{Discussion}

This paper began by evaluating students' perceptions of the complexity and compatibility of a 
new system introduced into a learning assignment that requires Internet research and $\mathrm{KM}$ activities for learning. Both $\mathrm{H} 1 \mathrm{a}$ and $\mathrm{H} 1 \mathrm{~b}$ were supported; although students were familiar with Moodle (the university's learning management system), most reported that Pearltrees was generally not complex to use for this type of assignment, and that it was compatible with their learning activities. Despite Pearltrees being unfamiliar to almost all students, its graphical, dragand-drop interface, integrated browser support, and live links to digital content made it easy for students to complete the required KM activities for the assignments. For instructors and system designers alike, these results suggest that the alignment of a system's affordances with the necessary activities and its ease of use can overcome habits and the difficulties of having to learn a new system.

To evaluate the impact of the order or timing at which a new system is introduced, students' perceptions of the complexity and compatibility of Pearltrees were compared between the first and second assignments in each course. Those students who used Pearltrees for the second assignment had less positive perceptions ( $\mathrm{H} 2 \mathrm{a}$ and $\mathrm{H} 2 \mathrm{~b}$ were supported, but $\mathrm{H} 2 \mathrm{~b}$ is only supported at the $90 \%$ confidence level). This suggests that there is an interaction between the timing of the introduction of a new ICT system and students' perceptions of it, with new systems perceived as being less compatible and more complex when introduced late in the semester. For educators, these results suggest important implications when introducing new systems into learning activities. If new systems are to be introduced as part of an assignment, instructors should organize these assignments early in the semester when students have more time and motivation to dedicate to learning the new system and before habits have been formed. Instructors may even consider providing additional time at the beginning of the assignment to allow students to explore and become familiar with the system prior to beginning the actual assignment.

In exploring the knowledge management activities of knowledge gathering, analysis, construction, and sharing against students' responses regarding the affordances of Moodle and Pearltrees, several strengths and weaknesses emerged in each ICT system. Students frequently mentioned Moodle's discussion capabilities as a strength of that system, suggesting that systems built or modified to support KM activities for learning must provide tools for students to easily integrate discussions into the activities to facilitate knowledge analysis, construction, and sharing.

On the other hand, many students preferred Pearltrees' graphical interface that supports and simplifies the creation of visual, hierarchical organizations of digital media. Students also felt that Pearltrees' affordances for sharing resources were superior to those of Moodle because Pearltrees provides live links to the relevant content. Design implications therefore suggest that a new or improved system should provide a method for sharing live links to facilitate the exchange of digital media. Other system requirements include mature communication tools to simplify sharing and discussion of digital resources with some form of notification of new content, and an interface that enables the creation and visualization of relationally organized media to scaffold the integration of multiple resources.

Additionally, although not specifically a design implication, students mentioned preferring to have all of their learning activities and resources in one place. This suggests that priority should be given to providing a single system rather than requiring multiple systems for such activities.

Finally, at least one student mentioned that data stored in Pearltrees was public, while data stored in Moodle was private to the student and instructor or at least to the course. Pearltrees intentionally makes user accounts public by default; only paid accounts can be private. The public nature of Pearltrees enables exploration of other individuals' curated media; in fact, Pearltrees suggests curated collections with similar digital content and notifies users when someone has "picked the same pearl." Although this capability to explore and find like-minded others is considered a benefit, designers should allow students to control the visibility of their curated digital media.

\section{Limitations and Future Work}

This research was conducted at a major polytechnic university in the northeastern United States and included graduate students in three traditional (face-toface) courses in the Information Systems discipline. To ensure a level of consistency in the assignments, all three courses were taught by the same instructor. Together, these factors may limit the generalizability of the findings. Future studies should repeat this research in undergraduate courses, distance learning courses, and in other types of courses at other types of universities.

In addition, this research compares two different systems that provide similar, KM-related affordances. Despite the rationale of selecting Moodle and Pearltrees for this research, additional knowledge can be gained by repeating this study using other types of systems, including actual KM systems such as Microsoft SharePoint, or other Web 2.0 technologies that support the key KM activities (e.g. Pinterest). 
Because every system will provide somewhat different affordances, or implement those affordances in unique ways, additional design implications may emerge from additional system comparisons.

\section{Conclusion}

In today's knowledge economy, creating, sharing, and utilizing knowledge is essential for individuals and organizations to achieve success. While corporations have invested heavily in mature KM systems, such activities are still not well supported in the educational domain. This research lays the foundation for identifying appropriate ICT systems that would allow KM-style learning activities to be seamlessly integrated into higher education by determining the affordances that ICT systems must provide, and suggesting the optimum timing for the introduction of these systems, in order for students to have a positive experience applying knowledge management for learning.

\section{Acknowledgements}

This paper is based on one of several studies included in a Ph.D. dissertation [5]. We thank the other members of the committee for their valuable contributions to this research. The University of Agder generously provided the second author, who was a Visiting Scientist there, with a travel grant to help support her presentation at HICSS.

\section{References}

[1] Agarwal, R., and E. Karahanna, "Time flies when you're having fun: Cognitive absorbption and beliefs about information technology usage", MIS Quarterly, 2000, pp. 665-694.

[2] Boyatzis, R.E. Transforming qualitative information: Thematic analysis and code development. Sage, 1998.

[3] Chatti, M.A., R. Klamma, M. Jarke, and A. Naeve, "The web 2.0 driven SECI model based learning process", Proceedings of the $7^{\text {th }}$ IEEE International Conference on Advanced Learning Technologies, 2007, pp. 780-782.

[4] Cheng, J., C. Kulkarni, and S. Klemmer, "Tools for predicting drop-off in large online classes", CSCW ' 13 Companion San Antonio, TX, 2013, pp. 121-124.

[5] Collins, R., “Assessing Learning Outcomes and Social Capital Formation Resulting from the Use and Sharing of Internet Knowledge Resources," Doctoral Dissertation, 2015, NJIT.
[6] Cress, U., and J. Kimmerle, "Theoretical framework of collaborative knowledge building with wikis - A systemic and cognitive perspective", Proceedings of the $7^{\text {th }}$ Computer Supported Collaborative Learning Conference, 2007, pp. 153-161.

[7] Cress, U., and J. Kimmerle, "Systemic and cognitive view on collaborative knowledge building with wikis", Computer Supported Collaborative Learning 3, 2008, pp. 105-122.

[8] Davenport, T., and L. Prusak, Working Knowledge: How Organizations Manage What They Know, Boston, MA: Harvard Business School Press, 2007.

[9] Grosseck,G., "To use or not to use web 2.0 in higher education?", Procedia-Social and Behavioral Sciences 1.1, 2009, pp. 478-482.

[10] Hiltz, S.R., The virtual classroom: Learning without limits via computer networks, Norwood, NJ: Intellect Books, 1994.

[11] Ivanova, M., and T. Ivanova, "Web 2.0 and web 3.0 environments: Possibilities for authoring and knowledge representation", Revista de Informatica Sociala 7(12), 2009, pp. 7-21.

[12] Kidwell, J.J., K. Vander Linde, and S.L. Johnson, "Applying corporate knowledge management practices in higher education", Educause Quarterly 23.4, 2000, pp. 2833.

[13] Kuo, R.Z., and G.G. Lee, "Knowledge management system adoption: Exploring the effects of empowering leadership, tas-technology fit and compatibility", Behaviour \& Information Technology 30.1, 2011, pp. 113-129.

[14] Lee, Y.H., Y.C. Hsieh, and C.N. Hsu, "Adding innovation diffusion theory to the technology acceptance model: Supporting employees' intentions to use e-learning systems", Educational Technology \& Society 14.4, 2011, pp. 124-137.

[15] Licurse, M.Y., and T.S. Cook, "PearlTrees web-based interface for teaching informatics in the radiology residency", SPIE Medical Imaging, International Society for Optics and Photonics, 2015, n.p.

[16] Limayem, M., S.G. Hirt, and C.M.K. Cheung, "How habit limits the predictive power of intention: The case of Information Systems continuance", MIS Quarterly 31.4, 2007, pp. 705-737.

[17] Glaser, B.G. Theoretical sensitivity: Advances in the methodology of grounded theory. Sociology Pr, 1978.

[18] McLoughlin, C., and M.J.W. Lee, "Social software and participatory learning: Pedagogical choices with technology affordances in the Web 2.0 era", ICT: Providing choices for learners and learning, Singapore, 2007, pp. 664-675. 
[19] Moore, G.C., and I. Benbasat, "Development of an instrument to measure the perceptions of adopting an information technology innovation", Information Systems Research 2(3), 1991, pp. 192-222.

[20] O'Reilly, T., "What is web 2.0? Design patterns and business models for the next generation of software", Retrieved May 17, 2012 from http://oreilly.com/web2/archive/what-is-web-20.html

[21] Pata, K., "Modeling spaces for self-directed learning at university courses", Journal of Educational Technology \& Society 12(3), 2009, pp. 23-43.

[22] Purser, E.R., A. Towndrow, and A. Aranguiz, "Realising the potential of peer-to-peer learning: Taming a MOOC with social media", eLearning Papers 33, 2013, pp. 1-5.

[23] Rogers, E.M., and F.F. Shoemaker, "Communication of innovations: A cross-cultural approach", 1971, n.p.

[24] Rowley, J., "Is higher education ready for knowledge management?", International Journal of Educational Management 14.7, 2000, pp. 325-333.

[25] Sunalai, S., and M. Beyerlein, "Exploring knowledge management in higher education institutions: Processes, influences, and outcomes", Academy of Educational Leadership Journal 19.3, 2015, pp. 289-308.

[26] Thompson, R.L., and C.A. Higgins, "Personal computing: Toward a conceptual model of utilization", MIS Quarterly 15(1), 1991, n.p.

[27] Top, E., "Blogging as a social medium in undergraduate courses: Sense of community best predictor of perceived learning", Internet and Higher Education 15(1), 2009, pp. 24-28.

[28] Tornatzky, L.G., and K.J. Klein, "Innovation characteristics and innovation adoption-implementation: A meta-analysis of findings", IEEE Transactions on Engineering Management 1, 1982, pp. 28-45.

[29] Trant, J., "Studying social tagging and folksonomy: A review and framework", Journal of Digital Information 10(1), 2009, pp. 1-42.
[30] Venkatesh, V., and S.A. Brown, "Research essay bridging the qualitative-quantitative divide: Guidelines for conducting mixed methods", MIS Quarterly 37(1), 2013, pp. $1-34$.

[31] Yew, J., F. Gibson, and S. Teasley, "Learning by tagging: Group knowledge formation in a self-organizing learning community", Proceedings of the $7^{\text {th }}$ International Conference on the Learning Sciences, 2006, pp. 1010-1011.

[32] Hay Y,S, B. Kim, H. Lee, and Y.G. Kim. "The effects of individual motivations and social capital on employees' tacit and explicit knowledge sharing intentions", International Journal of Information Management 33, 2013, pp. 356-366.

[33] Liu, Y., and J.S. Phillips. "Examining the antecedents of knowledge sharing in facilitating team innovativeness from a multilevel perspective", International Journal of Information Management 31, 2013, pp. 44-52.

[34] Thoms, B., N. Garrett, J.C. Herrera, and T. Ryan. "Understanding the roles of knowledge sharing and trust in online learning communities", Proceedings of the $41^{\text {st }}$ Hawaii International Conference on System Sciences, 2008, pp. 1-10.

[35] Mason, J., and P Lefrere. "Trust, collaboration, elearning and organizational transformation", International Journal of Training and Development 7(4), 2003, pp. 259270.

[36] Liaw, S.S., G-D Chen, and H-M Huang. "Users' attitudes toward Web-based collaborative learning systems for knowledge management", Computers \& Education 50, 2008, pp. 950-961.

[37] Gagne, E.D., C.W. Yekovich, and F.R. Yekovich. The cognitive psychology of school learning ( $2^{\text {nd }}$ ed.). New York: Harper Collins. 1993.

[38] Liaw, S.S. "Developing a Web assisted knowledge construction system based on the approach of constructivist knowledge analysis of tasks", Computers in Human Behavior 21(1), 2005, pp. 29-44. 